\title{
Uncoupling protein-2: evidence for its function as a metabolic regulator
}

\author{
M. C.Saleh ${ }^{1}$, M. B. Wheeler ${ }^{2}$, C. B. Chan ${ }^{1}$ \\ ${ }^{1}$ Department of Anatomy and Physiology, University of Prince Edward Island, Charlottetown, PE I, Canada \\ ${ }^{2}$ Departments of Medicine and Physiology, University of Toronto, Toronto, Ontario, Canada
}

\begin{abstract}
Uncoupling protein-2, discovered in 1997, belongs to a family of inner mitochondrial membrane proteins that, in general, function as carriers. The function(s) of uncoupling protein-2 have not yet been definitively described. However, mounting evidence suggests that uncoupling protein-2 could act in multiple tissues as a regulator of lipid metabolism. A role as a modulator of reactive oxygen species as a defence against infection is also postulated. In this review, a brief overview of the general and specific properties of uncoupling protein- 2 is given and evidence for metabolic and immune regulatory functions is summarized.
\end{abstract}

Uncoupling protein-2 could have particular importance in the regulation of lipid metabolism in adipose tissue and skeletal muscle. In addition, its ability to inhibit insulin secretion could also promote fat utilization over storage. Inhibition by uncoupling protein-2 of reactive oxygen species formation in macrophages and other tissues could have implications for regulation of immune function. The possibility of functions of uncoupling protein-2 in other tissues such as the brain are beginning to emerge. [Diabetologia (2002) 45: 174-187]

Keywords Metabolism, uncoupling protein, mitochondria, reactive oxygen species, energy balance.
Uncoupling protein-2 (UCP2) was discovered in 1997 but a definitive understanding of its functions has so far eluded investigators. Potential roles include regulating fat metabolism directly and indirectly via effects on insulin secretion. Also, UCP2 could also neg-

Received: 9 April and in revised form: 24 October 2001

Corresponding author: C.B. Chan, Department of Anatomy and Physiology, University of Prince Edward Island, 550 University Avenue, Charlottetown, PE I C1A 4P3, Canada, email: cchan@upei.ca

Abbreviations: BAT, Brown adipose tissue; CoQ, coenzyme Q (ubiquinone); $\mathrm{CRH}$, corticotrophin-releasing hormone; $\mathrm{Cyt}$ C, cytochrome C; ETC, electron transport chain; GSIS, glucose-stimulated insulin secretion; $\mathrm{HNF}$, hepatic nuclear factor; $\mathrm{H}_{2} \mathrm{O}_{2}$, hydrogen peroxide; $\mathrm{K}_{\text {ATP }}$ ATP-dependent potassium channel; LPS, lipopolysaccharide; NPY, neuropeptide Y; PPAR, peroxisome proliferator-activated receptor; ROS, reactive oxygen species; UCP, uncoupling protein; WAT, white adipose tissue; ZDF, Zucker diabetic fatty; $\Delta \mu_{\mathrm{H}+}$, proton electrochemical gradient atively modulate the production of reactive oxygen species (ROS). Although evidence in support of these functions is correlational, research on UCP2 mechanisms of action has recently been published. Studies of polymorphisms in the uncoupling protein-2 gene have not been included in detail here but are reviewed elsewhere $[1,2]$. For an in depth discussion of the uncoupling protein family of proteins, readers are referred to recent reviews $[1,3]$.

\section{Chemical properties of uncoupling proteins}

Mitochondrial metabolism generates more than $90 \%$ of the ATP required by organisms for routine cellular processes. The efficiency of ATP formation could be altered by demand, by drugs or by pathological processes. Uncoupling agents dissociate fuel oxidation in the electron transport chain of mitochondria from phosphorylation of substrate, namely ADP. Normally, glucose-derived $\mathrm{NADH}$ and $\mathrm{FADH}_{2}$ stimulate 


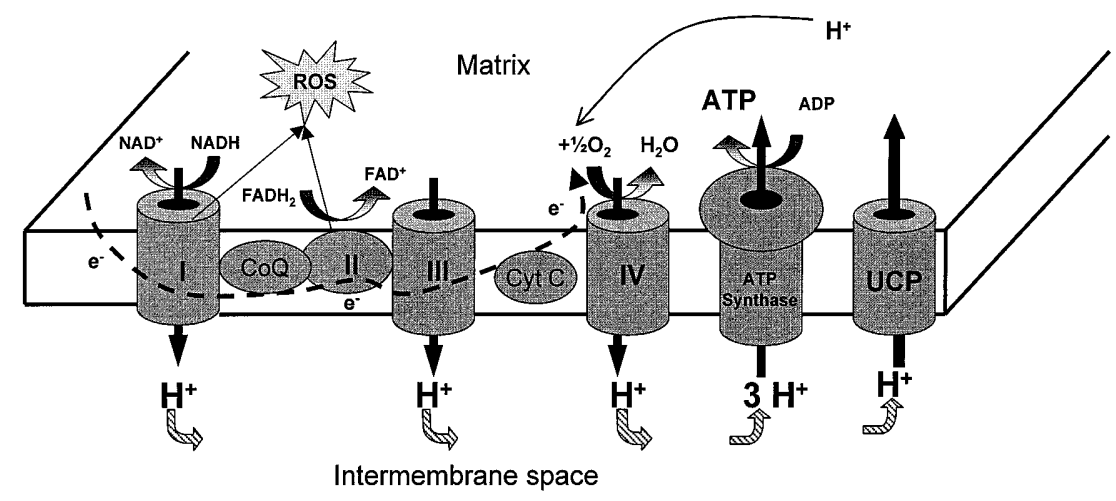

Fig.1. Coupled vs uncoupled cellular respiration: in a tightly coupled state, $\mathrm{H}^{+}$re-enters the mitochondrial matrix through ATP synthase to generate ATP from ADP and $\mathrm{P}_{\mathrm{i}}$. In less tightly coupled states, $\mathrm{H}^{+}$can transit the membrane via uncoupling proteins (UCP), thereby resulting in oxidation of glucose without concomitant production of ATP. Mechanism of ROS formation in cells: when the proton-motive force is large, the half-life of superoxide-generating electron transport intermediates such as ubisemiquinone is prolonged. CoQ, coenzyme $\mathrm{Q}$ (ubiquinone); cyt $\mathrm{C}$, cytochrome $\mathrm{C}$

the enzyme complexes (I-IV) of the electron transport chain to pump $\mathrm{H}^{+}$out of the mitochondrial matrix (Fig.1). This creates a large electrochemical gradient of about $-170 \mathrm{mV}$, known as the proton-motive force. In a tightly coupled system, protons can only re-enter the mitochondrial matrix via ATP synthase with the potential energy derived from the protonmotive force captured as the high energy phosphate bond $(\sim \mathrm{P})$ in ATP. The terminal step in the electron transport chain is the reaction $2 \mathrm{H}^{+}+2 \mathrm{e}^{-}+1 / 2$ $\mathrm{O}_{2} \rightarrow \mathrm{H}_{2} \mathrm{O}$, thereby keeping the intracellular proton concentration low. In an uncoupled state, proton reentry bypasses ATP synthase, reducing the protonmotive force without capturing the potential energy, which is released as heat [4].

Nature has provided proteins that act as uncouplers of oxidative phosphorylation. The most studied is uncoupling protein-1 (UCP1, thermogenin), found in abundance in the brown adipose tissue (BAT) of rodents, neonates of other mammalian species [4], and in small quantities in white adipose tissue (WAT). Here it appears to be expressed in multilocular cells similar to brown adipocytes [5]. Uncoupling protein-1 is part of a superfamily of proteins that includes mitochondrial carriers for ADP and ATP, and oxoglutarate and malate among others, plus related proteins in invertebrates, plants and fungi $[4,6,7]$. It might be surmised that cells expressing UCPs can metabolize fuels without production of $\sim \mathrm{P}$, resulting instead in the production of heat. This process might therefore regulate metabolic efficiency and provide a mechanism for non-shivering thermogenesis. However, the near absence of UCP1 in adult mammals, in- cluding humans, has led to the hypothesis that equivalent molecules must exist to perform thermogenic and other regulatory functions.

\section{Discovery of UCP2}

In 1997 two groups using cloning approaches nearly simultaneously reported the existence of a protein having high homology to UCP1 that was named UCP2 $[8,9]$. Uncoupling protein-2 transfected into yeast slows its growth and dissipates its mitochondrial membrane potential $[8,9]$. The $U C P 2$ gene is found on human chromosome 11 (mouse chromosome 7) in a region linked to obesity [8]. Coincidentally, a third laboratory investigating the phenotype of UCP1 null mutant (-I-) mice failed to observe development of obesity, as might be expected if UCP1 was solely responsible for diet-induced thermogenesis. Instead, they identified the induction of UCP2 as a possible explanation [10]. Subsequently, two other mammalian homologues were added to the family and termed UCP3 [11, 12] and UCP4 [13]. Uncoupling protein- 4 and a fifth protein, brain mitochondrial carrier protein-1 [14] have low homology with UCPs $1-3[1]$.

\section{Localization and chemical similarities of UCP2 to other proteins}

Northern blot or PCR-based analyses show fairly ubiquitous expression of $U C P 2$ mRNA but are in abundance in WAT, immune-associated tissues such as spleen and macrophages [8] and pancreatic islets $[15,16]$. Uncoupling protein-2 mRNA is also expressed in skeletal muscle, although at lower amounts than UCP3 mRNA [17]. The distribution of UCP2 mRNA in areas of the brain associated with metabolic and thermal regulation in both rodents [18] and nonhuman primates [19] is also intriguing. Quantitative studies of protein expression are hampered by the lack of a suitable antibody for immunoblotting $[3,20]$. However, immunocytochemical analysis shows that the UCP2 protein is present in pancreatic 
endocrine but not in exocrine tissues [15]. A recent description of an UCP2 antibody suitable for western blotting [21] should lead to a better understanding of the protein's regulation. For example, that study [21] suggests that while the $U C P 2 \mathrm{mRNA}$ is detected in both WAT and skeletal muscle, the protein is only detectable in WAT.

Uncoupling protein-2 shares about 56\% [9] and UCP3 about $57 \%$ amino acid identity with UCP1. Uncoupling protein-2 is highly conserved among species, having $95 \%$ homology between human and murine entities [9] and about $82 \%$ between mammalian and fish sequences [22]. The human UCP2 gene has eight exons [23], but translation is initiated in exon 3 [24] with the six translated exons encoding a protein of 309 amino acids with six transmembrane domains [23]. The genomic and protein structures are highly conserved with UCP1 [25]. There are three mitochondrial carrier protein motifs predicting ion transport capabilities and both UCP2 and UCP1 catalyse a $\mathrm{H}^{+}$flux across the mitochondrial membrane [9] and in reconstituted liposomes [26].

The mechanism of UCP1's activity is currently explained by two hypotheses, the buffering model [27] and the protonophoretic model [28]. While the relative merit of these models, which differ mainly in how non-esterified fatty acids interact with UCP1 [29], is still being debated [1, 3], a key point is that UCP1 has both a NEFA [30] and a purine binding site $[31,32]$. There are conflicting data on the NEFA and nucleotide sensitivity of UCP2 $[26,33]$ but in an artificial vesicle system, UCP2 had identical properties as UCP1, including $\mathrm{H}^{+}$transport, NEFA and nucleotide binding, and dependence upon coenzyme $\mathrm{Q}$ for activation [34].

\section{Functions of UCP1}

The known functions of UCP1 provide a starting place for research into the physiological importance of the novel UCPs. The observation that UCP1 -/mice cannot maintain body temperature when coldchallenged [10] proves the primary role of UCP1 in cold-activated nonshivering thermoregulation of rodents. When mice are acutely exposed to cold, activation of $\beta 3$-adrenergic receptors increases lipolysis within the BAT. The increase in NEFAs activates proton transport by UCP1 [35]. Long term cold stress increases circulating thyroid hormone concentrations and potentiates the sympathetic response [36]. Triiodothyronine treatment of brown adipocytes increases UCP1 protein expression, probably by stabilizing the mRNA transcript $[36,37]$ in addition to inducing gene transcription [38]. Uncoupling protein-1 is also an important controller of body weight in rodents. Brown adipose tissue-ablated rats become overweight [38] and genetically obese rodents uni- formly have reduced amounts of BAT and sluggish thermogenic responses to cold or dietary stimulation [35]. Leptin, a hormonal regulator of body fat, upregulates UCP1 expression in BAT via central sympathetic centres [39]. Therefore, obese rodents producing nonfunctional leptin (like $o b / o b$ ) [40] or having leptin receptor mutations (like $d b / d b$ or $f a / f a$ ) [41] have poor diet-induced BAT-dependent nonshivering thermogenesis, promoting weight accretion [4]. However, in the studies with UCP1 -/- mice, excessive weight gain is not observed [10] leading to the conclusion that other factors regulating diet-induced thermogenesis exist. The initial observations that UCP2 is strongly induced in BAT [42] and WAT [16] in response to leptin treatment led to a flurry of experiments to determine the implications. The discovery of UCP2 in WAT and to a lesser extent in skeletal muscle, both tissues being potentially important for diet-induced thermogenesis [43], was a further impetus to pursue this line of questioning.

\section{Postulated functions of UCP2}

To date the potential functions for UCP2 include thermoregulation, metabolic regulation and defence against infection. Although yeast transfected with UCP2 emit more heat [44], UCP2 does not seem to participate in adaptive thermal responses in rodents because UCP1 -/- mice are cold-sensitive despite upregulation of UCP2 [10]. Moreover, although cold exposure increases $U C P 2$ expression [45-47] and $d b / d b$ mice have an impaired $U C P 2$ response to cold [47], UCP2 -/- mice are not cold-sensitive [48]. Ectothermic fish also express UCP2-like proteins but, because the body temperature of these fish reflects that of the ambient environment, it is presumed that UCPs play non-thermogenic roles in metabolism [22]. Conversely, in birds a UCP-like protein (avUCP) is upregulated by conditions that induced non-shivering muscle thermogenesis [49]. Thyroid hormone-dependent variations in $U C P 2$ expression could contribute to adaptations in resting metabolic rate [50,51]. The $U C P 2$ gene promoter region has two putative thyroid response elements [52] but the ability of thyroid hormone to induce $U C P 2 \mathrm{mRNA}$ is tissue-specific [53] and not correlated with an increase in nonphosphorylating mitochondrial metabolism in mice [50]. Uncoupling protein- 2 is upregulated by fasting in rodent skeletal muscle $[45,54]$, which is not consistent with it having a role in diet-induced thermogenesis. Likewise, hypocaloric diets increase UCP2 mRNA expression in both WAT and skeletal muscle of human subjects [17]. Because the evidence is weak that UCP2 contributes substantially to adaptive thermogenesis under physiological conditions, this review emphasizes possible metabolic and immune defence functions. 


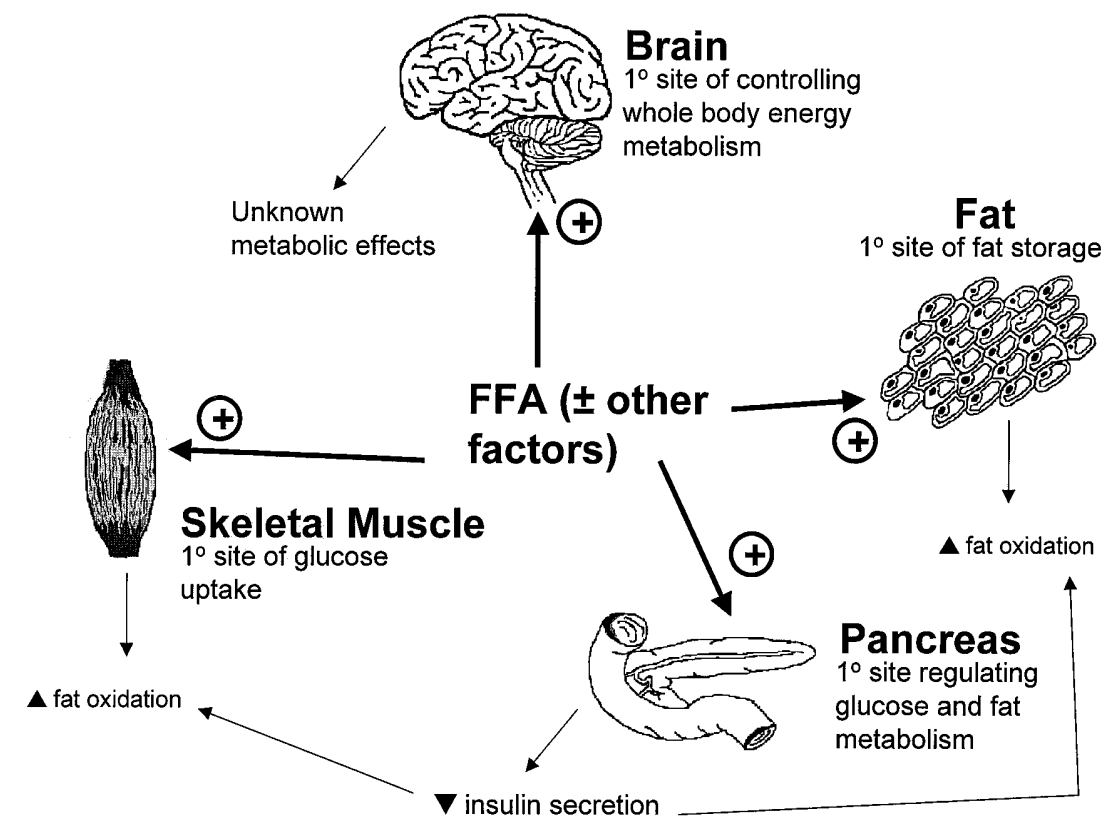

Fig. 2. Potential sites of UCP2-mediated metabolic regulation

\section{Fuel metabolism}

The potential sites at which UCP2 could regulate fuel metabolism include adipose tissue, skeletal muscle, endocrine pancreas and brain (Fig. 2).

Adipose tissue. In BAT and WAT the properties of UCP2 appear to be suited to the regulation of fuel metabolism. For example, BAT UCP2 could regulate the use of lipids as fuel substrate for UCP1-mediated thermogenesis [54]. In rats, $U C P 2$ expression in BAT is decreased after $48 \mathrm{~h}$ of starvation and restored to normal within $72 \mathrm{~h}$ of refeeding [54]. Refed rats have accelerated fat deposition without an increase in food intake, suggesting that UCP2 could enhance lipogenesis in the aftermath of starvation as a means of replenishing depleted fat stores [54]. However, a role for UCP2 in adaptive thermogenesis in BAT has not been completely ruled out [55].

Studies in WAT are more applicable to human physiology and more strongly suggest an association of UCP2 with situations where fat metabolism is altered. In adipocytes, uncoupling of oxidative metabolism depresses lipogenesis [56]. Rodent studies show that $U C P 2$ mRNA induction occurs with excessive fat intake $[57,58]$. The increase is not dependent simply on caloric intake, because there is no effect on UCP2 expression of highly palatable diets with modestly ( $<20 \%$ ) increased fat content [59]. The ability of some individuals to resist weight gain might be related to their ability to upregulate UCP2, since mice resistant to weight gain on a high fat $\operatorname{diet}(\mathrm{A} / \mathrm{J})$ induce UCP2 in WAT whereas obesity-prone mice (C57BL/6
J) do not $[8,60,61]$. Mice congenic for a segment of chromosome 7 containing polymorphisms in the $U C P 2$ locus are susceptible to weight gain on a high fat diet. However, the congenic segment also contains the genes for $T U B$ and $U C P 3$, thereby limiting interpretation [62]. Thus, an impaired or delayed enhancement of $U C P 2$ gene expression in adipose tissue in response to increased lipid intake could contribute to the onset of obesity in rodents.

In humans, the putative contribution of altered $U C P 2$ gene expression in WAT to the pathogenesis of obesity is of great interest but unresolved. The quantity of $U C P 2$ mRNA in subcutaneous abdominal fat is positively correlated with BMI [17], which is consistent with the increased gene expression observed in WAT of $o b / o b$ and $d b / d b$ mice $[9,47]$. However, others find no difference in $U C P 2$ expression in subcutaneous abdominal fat in obese compared with lean subjects [63]. Moreover, in omental fat $U C P 2$ mRNA is lower in the obese patients and remains lower after weight reducing surgery. One difference between the two studies is the effect of the weight loss intervention on plasma NEFA concentrations. In the first, plasma NEFA increases by $30 \%$ in obese and $90 \%$ in lean subjects [17]. In the second, no difference is seen before and 10 months after weight loss surgery [63]. A more recent study supports the idea that $U C P 2$ expression in subcutaneous adipose tissue is negatively correlated with BMI but no short term regulation by NEFA is observed [64]. Lastly, $U C P 2$ in healthy male subjects is described as variable, with no relation to resting metabolic rate [65].

Attempts to demonstrate that NEFA can directly influence $U C P 2$ expression in vivo also result in conflicting conclusions. Severe hyperlipidaemia (tenfold increase in plasma NEFA) created by prolonged infusion of triglyceride emulsions increases $U C P 2$ gene 
expression in WAT by $120 \%$ in normal weight subjects [66] but a moderate threefold increase in plasma NEFA has no effect [67]. Conjugated linoleic acid given in the diet of mice causes marked loss of weight and fat mass coordinate with a sixfold induction of $U C P 2$ in WAT [68]. The magnitude of the conjugated linoleic acid effect far exceeds that of the triglyceride emulsions. The $\mathrm{n}-3$ polyunsaturated fatty acids found in fish oils also induce UCP2 expression in WAT, and are associated with lower fat pad weight and lower leptin concentrations in $\mathrm{KK}^{\mathrm{ay}}$ mice [69].

With in vivo studies it is difficult to assess whether interventions affect UCP2 directly or indirectly. Diet or starvation alter hormone concentrations might also regulate UCP2. Of particular interest are insulin and leptin, because both influence UCP1 [70, 71]. In addition, both fasting plasma leptin [72] and insulin concentrations $[72,73]$ are negatively correlated with WAT $U C P 2$ mRNA expression, although this finding is not supported by other data [65]. In wellcontrolled studies in rats, where leptin effects can be separated from those of weight loss, both intracerebroventricular [42] and peripherally-administered leptin [74] increase $U C P 2$ expression in WAT. This effect is likely to be mediated by the sympathetic nervous system because leptin added directly to human adipocyte explants does not alter $U C P 2$ expression [75]. However, when circulating leptin concentrations are increased threefold by inhibiting the sympathetic nervous system over $18 \mathrm{~h}$, no changes in WAT $U C P 2$ mRNA are observed [76]. This null effect is similar to studies in which feeding increases leptin but not $U C P 2$ in subcutaneous abdominal fat [72]. Leptin is not obligatory for $U C P 2$ expression in fat, because $o b / o b$ mice have increased $U C P 2[9,77]$ and exogenous leptin treatment to these mice does not further increase $U C P 2$ expression [77]. Less is known about the effect of insulin on UCP2 mRNA in WAT. Uncoupling protein-2 expression is not acutely regulated by plasma insulin as shown by hyperinsulinaemic clamp studies [17] or postprandial measurements [72]. In contrast, insulinopenic rats have increased $U C P 2$ expression that is normalized by insulin therapy [78]. However, as insulin treatment also ameliorates the hyperlipidaemia associated with diabetes [78], the effects of insulin could be indirect. As with the lipid infusion studies, it could be necessary to invoke an intense hormonal stimulus in order to see effects on $U C P 2$ transcription. It will be important to learn more about the post-translational effects of putative regulators of UCP2 because of the potential of its more acute activation.

The mechanism by which UCP2 activity in WAT is putatively increased by NEFA exposure is not known. UCP1 is directly activated by NEFA posttranslationally [79]. However, so far the evidence is far stronger for transcriptional than post-translational induction of UCP2 activity by NEFA [33]. The per- oxisome proliferator-activated receptors (PPARs) act as activators of transcription [80]. Peroxisome proliferator-activated receptor- $\gamma$ is activated by NEFA and induces genes associated with fat metabolism [81]. In adipose tissue, agonists of PPAR- $\gamma$ augment $U C P 2$ expression in rodents and humans [75, 82-85]. Peroxisome proliferator response elements are associated with the promoter regions of the $U C P 2$ [52] and the $U C P 3$ genes [86]. Responsiveness of $U C P 2$ transcription to PPAR $\gamma$ is lost upon mutation of specific motifs in an enhancer region of the UCP2 gene but because PPAR $\gamma$ does not bind to this region, its action is thought to be indirect [87].

An alternative to the PPAR hypothesis of $U C P 2$ transcriptional regulation is the potential for sympathetic nervous system-mediated upregulation. This hypothesis is viable because conditions such as fasting and cold exposure that activate lipolysis are associated with sympathetic activation. The 5'-flanking region of the $U C P 2$ gene contains multiple cyclic AMP response elements $[52,88]$. In clonal adipocytes, cyclic AMP-dependent protein kinase A activation induces $U C P 2$ gene expression after $12 \mathrm{~h}$ exposure [88]. However, neither in vitro exposure to $\beta 2$ - or $\beta 3$-sympathetic agonists $[8,88]$ or orally administered BRL 35135 [73] induces $U C P 2$ expression in WAT. In contrast, BRL 35135 given intraperitoneally induces WAT UCP2 by two to threefold [89]. Inhibition of the sympathetic nervous system using toxins has no effect on epididymal adipose UCP2 [76]. Clearly, further work using in vivo models is required to understand $U C P 2$ transcriptional regulation. In one of the first reports to emerge showing rigorous quantification of protein content, an increase in UCP2 protein without any change in mRNA is observed in stomach and lung after starvation but no results are reported for WAT [21]. These data do, however, raise the possibility of post-transcriptional regulation of $\mathrm{UCP} 2$ activity by the metabolic state.

Skeletal muscle. The pattern of changes in $U C P 2$ gene expression in muscle tissue is consistent with a role in the regulation of lipid metabolism. Experiments in rats show a pronounced increase in muscle $U C P 2$ mRNA in response to fasting $[45,54,90]$ that is blunted by pretreatment with an antilipolytic agent [90, 91]. Also, when fasted rats are treated with an inhibitor of NEFA flux through beta-oxidation, increases are observed in both serum NEFA and soleus muscle (primarily oxidative) UCP2 mRNA [91]. However, $U C P 2$ gene expression is attenuated in the tibialis anterior muscle, a tissue that shifts between lipid oxidation and glycolytic metabolism [91]. While fasting produces upregulation of $U C P 2 \mathrm{mRNA}$, refeeding on a low fat diet causes $U C P 2$ mRNA in muscle tissue to plummet to below control values [92]. The fasting-induced increase in $U C P 2$ gene expression is maintained in rats refed a high fat diet [92]. These ob- 
servations suggest the existence of a positive feedback loop between NEFA flux and UCP2 gene expression in skeletal muscle such that in oxidativetype muscle tissue $U C P 2$ mRNA is regulated by serum NEFA concentrations while in oxidative-glycolytic-type muscle $U C P 2$ gene expression is regulated by NEFA flux in mitochondria [91, 92]. However, more recently others have raised the possibility that insulin resistance rather than NEFA is more closely linked to UCP2 adaptations to fasting and refeeding [92, 93].

In contrast, NEFA flux does not seem to be among the factors regulating $U C P 2$ gene expression in glycolytic muscle fibres because anti-lipolytic agents are ineffective in blocking the fasting-induced increase in $U C P 2$ mRNA in rat gastrocnemius muscle [55, 91]. High fat diet has no effect on $U C P 2$ gene expression in the gastrocnemius muscle of both rats $[57,94]$ and mice [95]. However, more recently a modestly high fat diet $(33 \%)$ upregulated UCP2 gene expression by about $75 \%$ in rat gastrocnemius muscle [59]. This increase is not correlated with weight gain, BAT mass, body temperature or plasma concentrations of leptin, insulin or triglycerides leading the authors to speculate that skeletal muscle UCP2 is significantly less labile than UCP2 found in BAT and WAT, thus requiring body fat stores to reach critical values before appreciable changes in local $U C P 2$ gene expression are observed [59]. Alterations in UCP2 mRNA coincident with shifts in muscle metabolism in response to substrate availability support a proposed role for UCP2 in lipid metabolism.

In humans, there are conflicting data for muscle $U C P 2$ gene expression correlations with $\mathrm{BMI}$ or the percentage of body fat $[17,96-99]$. In contrast, patients with Type II (non-insulin-dependent) diabetes mellitus show increased $U C P 2$ mRNA in the vastus lateralis muscle, a primarily oxidative-type tissue $[97,100]$. While fasting in both lean and non-diabetic obese subjects results in an increased $U C P 2$ gene expression $[17,100]$ no change is observed in diabetic patients [100]. To explain this phenomenon, the existence of an impaired lipolytic response by adipose tissue is proposed [100]. Given the apparent inducing effect of NEFAs on muscle UCP2 gene expression, the absence of a sufficient rise in serum NEFAs during calorie restriction in diabetic patients could preclude changes in muscle $U C P 2$. However, contrary findings are also reported. When weight loss is induced by dietary restriction rather than fasting, $U C P 2$ mRNA in vastus lateralis muscle increases slightly [96, 101]. Of interest, $U C P 2$ expression in the vastus lateralis muscle of tetraplegic patients is increased by nearly fourfold compared with able-bodied subjects. Expression is normalized by treating the paralysed patients with an electrically-stimulated leg cycling program [102]. After endurance training in able-bodied athletes, the ability of NEFA to in- crease muscle oxygen consumption is increased, an effect correlated with the increase in UCP 2 mRNA [103]. Because obese and Type II diabetic patients tend to have reduced physical activity, some of the changes observed in the studies cited above might be caused by inactivity.

Polyunsaturated NEFA such as $\omega-6$ fatty acids seem to influence $U C P 2$ expression by multiple intracellular pathways. Using L6 myotubes, both cyclic $\mathrm{AMP} /$ protein kinase A-dependent and PPAR $\beta$-dependent mechanisms of induction of gene transcription are detected. The cyclic AMP-dependent pathway is activated by cyclooxygenase-mediated processes [104].

Pancreatic islets. The lipid content of pancreatic islet beta cells must be carefully regulated to optimize insulin secretion. Glucose-stimulated insulin secretion (GSIS) is abolished in normal islets depleted of triglyceride [105] while toxic lipid accumulation is a postulated mechanism in the beta-cell failure observed in the Zucker diabetic fatty (ZDF) rat [106, 107]. The observation that $U C P 2$ gene expression is attenuated in the islets of ZDF rats [108] and is upregulated by high concentrations of leptin in normal islets [16, 106] or a PPAR- $\gamma$ ligand in ZDF islets [108] supports a role for UCP2 in the putative leptin-regulated pathway of intracellular fat homeostasis (Fig. 3).

Overexpression of UCP2 mRNA in rat islets [15, 109] or clonal beta cells $[109,110]$ blunts GSIS and lowers cellular ATP, which is suggestive of the uncoupling properties of UCP2 [15]. Moreover, overexpression of UCP2 in beta cells leads to depolarization of the mitochondrial membrane potential [109], a decrease in the ADP:O ratio, increased state 4 respiration [110] and reduced closure of ATP-dependent $\mathrm{K}^{+}$ $\left(K_{\text {ATP }}\right)$ channels [109]. Support for the hypothesis that UCP2 is a negative regulator of insulin secretion comes from investigations using UCP2 - /- mice. These mice have increased circulating insulin concentrations concomitant with reduced blood glucose in the fed state. Insulin secretion from glucose-stimulated isolated islets is also significantly enhanced and the ATP:ADP ratio is increased [111]. Conversely, overexpression of UCP2 in ZDF rat islets shows an increase in preproinsulin mRNA together with an improvement in GSIS [112]. Additional investigation is warranted to further elucidate the contribution of UCP2 in islets to intracellular lipid metabolism and the stimulus-secretion coupling of insulin release.

Little is known about the regulation of UCP2 expression in beta cells. Both leptin [16] and PPAR- $\gamma$ ligands [108] are reported to induce $U C P 2$ mRNA, implying that UCP2 could be regulated by NEFA [16] as described for other tissues. Indeed, chronic exposure of clonal beta cells to oleic acid impairs GSIS, lowers mitochondrial membrane potential and reduces the ATP:ADP ratio, correlating with increased $U C P 2$ 


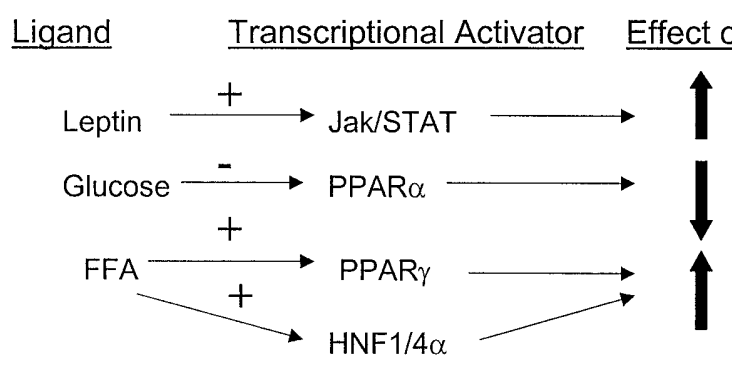

UCP2 effects on beta-cell function

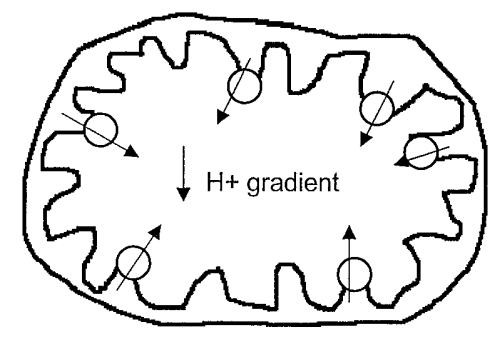

Fig.3. (Top) putative nutrient and hormonal regulators of pancreatic beta-cells. (Bottom) potential mechanisms of UCP2 action in beta-cells

mRNA and protein [113]. Glucose metabolism is also implicated in the regulation of $U C P 2$ transcription (Fig.3). The hepatic nuclear factor $4 \alpha(\mathrm{HNF} 4 \alpha)$ is a transcription factor expressed in islets, the absence of which leads to development of MODY1 [114]. When $\mathrm{HNF} 4 \alpha$ is increased, GSIS is suppressed and ATP generation is attenuated. Because of pleiotropic effects on the expression of mitochondrial TCA cycle enzymes, substrate metabolism is greatly inhibited. However, in addition to these effects, HNF4 $\alpha$ also elicits partial uncoupling of mitochondrial respiration that is accompanied by an increase in $U C P 2$ mRNA expression [115]. Also, HNF1 $\alpha$, a second transcription factor acting downstream of HNF4 $\alpha$ [115], induces a similar phenotype including the increase in $U C P 2$ and mitochondrial membrane depolarization [116]. Glucose could also directly alter UCP2 expression through negative regulation of PPAR $\alpha$ [117]. It is well-documented that chronic exposure of islets to high glucose causes high basal insulin secretion but reduces the response to increased glucose [118]. Beta cells exposed to high glucose have reduced $P P A R \alpha$ mRNA and protein within $6 \mathrm{~h}$ of exposure. A concomitant $75 \%$ reduction of $U C P 2$ mRNA is observed and basal insulin is increased [117]. The decrease in UCP2 is proposed to contribute to a decrease in NEFA oxidation, leading to increased cellular fatty acyl-CoA [117]. Together with increased glucose metabolism, such altered lipid partitioning is im-

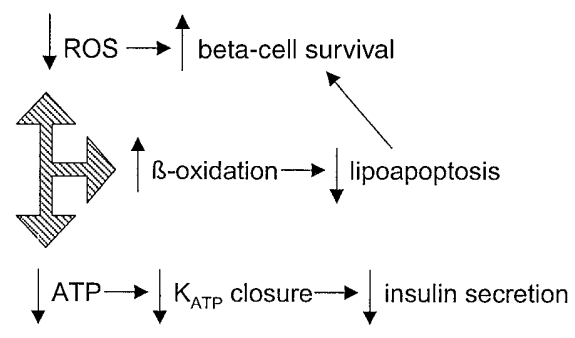

plicated in the development of glucolipotoxicity, which then leads to suppression of GSIS [119].

Central nervous system. Specific regions of the brain, particularly the hypothalamus, are associated with the regulation of peripheral metabolism. In rodents, $U C P 2 \mathrm{mRNA}$ is found in suprachiasmatic, arcuate and paraventricular nuclei of the hypothalamus and in the dorsomotor nucleus of the vagus nerve [18, 120]. In non-human primate hypothalamic centres, UCP2 is co-expressed in neurons producing neuropeptide Y (NPY), corticotrophin-releasing hormone $(\mathrm{CRH})$, oxytocin and vasopressin [19]. The metabolic importance of neuronal pathways involving NPY and CRH is well-known; thus UCP2 could regulate the signalling of efferent pathways to affect peripheral weight regulation $[19,120]$. In rats, cold exposure increases spinal cord, but not brain, $U C P 2$ mRNA by about $50 \%$ [121]. However, any changes in specific brain nuclei could be masked by the use of whole brain homogenates for northern blot analysis. The central nervous system remains an intriguing locus of $U C P 2$ expression where its function remains entirely hypothetical.

\section{Regulation of reactive oxygen species production}

Normally, mitochondrial respiration results in the formation of reactive oxygen species (ROS), such as superoxide and hydrogen peroxide $\left(\mathrm{H}_{2} \mathrm{O}_{2}\right)$ (Fig. 1). Experiments using isolated mitochondria show a positive correlation between the proton electrochemical gradient $\left(\Delta \mu_{\mathrm{H}_{+}}\right)$and ROS production [122] because electron flow down the electron transport chain is in- 
hibited, thereby prolonging the half-life of intermediates capable of reducing $\mathrm{O}_{2}$ to superoxide. Production of ROS is decreased by uncoupling agents that reduce $\Delta \mu_{\mathrm{H}+}$ [123]. Moderate concentrations of $\mathrm{H}_{2} \mathrm{O}_{2}$ are beneficial, regulating the redox state of the cell and modulating transcription factors involved in cell proliferation and differentiation [124, 125]. Oxidative bursts generating ROS also provide a defence against infectious agents [136]. At toxic concentrations, ROS are capable of damaging cellular membranes, proteins and DNA leading to eventual mitochondrial destruction and cellular apoptosis [123, 127, 128].

The hypothesis that UCP2 functions to limit ROS production is verified by studies in UCP2 -/- mice infected with Toxoplasma gondii. Macrophages from these mice generate $80 \%$ more ROS than control mice, brain lesion formation is markedly reduced and lethality of the infection absent [48]. Using clonal beta cells, others show that UCP2 overexpression reduces cell death induced by application of $\mathrm{H}_{2} \mathrm{O}_{2}$ [129]. Increased uncoupling in vascular endothelial cells induced by UCP1 overexpression reduces ROS formation caused by hyperglycaemia [130]. Since UCP1 is not likely to be expressed naturally in endothelia, UCP2 could be a candidate for such function under physiological conditions.

Several correlational studies support a role of UCPs in suppressing ROS formation. In nonparenchymal liver cells, induction of UCP2 is associated with a decrease in $\mathrm{H}_{2} \mathrm{O}_{2}$ production [131]. The $o b / o b$ mouse has increased susceptibility to inflammatory hepatic lesions associated with a $200 \%$ increase in ROS generation by hepatocyte mitochondria [132]. Models of fatty liver, including $o b / o b$ mice, exhibit an increase in $U C P 2$ mRNA, which is hypothesized to be an adaptive response to ROS $[132,133]$. Of interest, PPAR $-\gamma$ mRNA is increased in $o b / o b$ mouse hepatocytes and treatment with a PPAR- $\gamma$ ligand induces a further increase in $U C P 2$ expression [134]. In contrast to liver, the $U C P 2 \mathrm{mRNA}$ measured in macrophages of $o b / o b$ mice is decreased and ROS production is increased relative to normal mice [135]. As with other tissues, this suggests tissue-specific regulation of $U C P 2$ gene transcription.

Bacterial infection could involve systemic exposure to lipopolysaccharide (LPS), an endotoxin that induces fever and other elements of an immune response. Mice treated with LPS have increased UCP2 mRNA after 6 to $24 \mathrm{~h}$ [21, 136-138]. This correlates with an increase in core temperature but, because no increase in mitochondrial proton leak is detected [139], the pyrogenic mechanism might not rely on UCP2. However, in another study an increase in liver $U C P 2$ expression correlated with reduced $\mathrm{O}_{2}$ consumption, null effect of dinitrophenol as an uncoupler, and reduced mitochondrial membrane potential [139]. Although TNF- $\alpha$ has been implicated in LPS- mediated induction of $U C P 2$ [137, 138], knockout of the $T N F$ - $\alpha$ gene in $o b / o b$ mice results in a paradoxical increase in UCP2 gene expression [77]. Thus, the importance of cytokines such as TNF- $\alpha$ as regulators of UCP2 remains equivocal.

Altogether, these studies suggest that upregulation of UCP2 could be an adaptive response to inflammatory insult. While limited production of ROS might be helpful in eliminating invading organisms [48], the ability to suppress ROS production under other circumstances is essential to prevent excessive tissue damage.

\section{Relation of UCP2 with metabolic diseases}

Many reports have shown that UCP2 expression in tissues varies according to the metabolic status of the subject. Originally, it was postulated that a primary change in UCP2 activity might lead to a disease state; the most popular hypothesis was that low UCP2 would lead to the development of obesity based on its putative role in diet-induced thermogenesis. Although a number of polymorphisms in $U C P 2$ gene structure have been identified, only a few studies support a strong role for $U C P 2$ mutations in the pathogenesis of obesity [2].

In contrast with genetic linkage studies, many reports are consistent with the idea that UCP2 tissue expression adapts to changes in the metabolic state, in response to altered plasma NEFA concentrations or insulin sensitivity [91, 92]. It is therefore possible that chronic homeostatic disturbances could lead to maladaptive states, in which UCP2 might be an important participant.

The potential for UCP2 maladaptions to contribute to obesity has received considerable attention. Authors finding an inverse correlation between UCP2 and BMI in WAT suggest that the resultant increase in energy efficiency contributes to the pathogenesis and maintenance of an overweight state [72]. Although none of the UCP -/- mice $(1,2$ or 3$)$ is obese $[10,48,111,140,141]$ it remains to be determined how UCP2 interacts with other potential energy monitoring molecules to participate in weight homeostasis. Of interest are data showing that mice with skeletal muscle-specific induction of UCP3 have decreased body weight despite normal [142] or increased food intake [143]. The metabolic rate is increased, as is insulin sensitivity and glucose uptake, whereas adipose tissue mass is reduced by about $50 \%$ [143].

Unfortunately, genetically-defined rodent models of obesity do not provide a clear picture of what might apply to humans. In addition to the complications arising from the dominance of UCP1 in adaptive thermogenesis, there is considerable variability in reported tissue $U C P 2 \mathrm{mRNA}$. Since leptin appears 
to upregulate UCP2 [42, 74], it might be hypothesized that leptin-deficient or leptin-resistant animals would have attenuated $U C P 2$ expression. However, not only is leptin not essential for $U C P 2$ expression, it seems that even similar causes of obesity have disparate effects on $U C P 2$ expression $[9,16,89,144]$. Moreover, expression of $U C P 2$ in skeletal muscle of these rodents has rarely been reported. Although UCP3 is dominant in skeletal muscle, the large mass of the tissue increases the possibility that fluctuations of UCP2 content could have physiological relevance.

One explanation for the discrepancies could be the degree of diabetes coexisting with obesity in these animals. The $f a / f a$ rat is insulin resistant but not diabetic, whereas $o b / o b$ mice on a C57BL/6 J background exhibit mild diabetes [145] and the ZDF rat a more severe diabetes [146]. Type II diabetes mellitus is associated with hypertriglyceridaemia, hypercholesterolaemia and increased NEFA in plasma. As noted above, UCP2 expression in skeletal muscle of human diabetic patients is increased [97, 100]. In $f a / f a$ rat muscle, no difference [144] or a decrease in expression is reported [89]. In contrast, non-obese rats made diabetic by streptozotocin injection initially have increased UCP 2 in both WAT and skeletal muscle. After 3 weeks without insulin therapy, $U C P 2$ mRNA in WAT remains increased whereas that in skeletal muscle returns to baseline [78]. Although there seems to be an adaptive response of UCP2 to diabetes, particularly in skeletal muscle, the relevance of this observation remains to be determined.

Obesity and diabetes are also associated with deranged insulin secretion and it has been hypothesized that UCP2 could play a part in the development of insulin insufficiency in diabetes. Rats fed a high fat diet for 3 weeks [109] and hyperlipidaemic, diabetic $o b / o b$ mice [111] have increased islet UCP2 mRNA expression. Such lipid-associated upregulation could contribute to the development of insulin insufficiency and subsequent hyperglycaemia. Since hyperglycaemia also induces $U C P 2$ expression [117], it is possible that a feed-forward loop is generated which further exacerbates the insulin insufficiency, leading to the onset and progression of frank diabetes. Evidence for this hypothesis is provided by experiments showing that when $o b / o b$ mice are crossed with UCP2 gene knockout mice, there is an improvement in glucose tolerance accompanied by increased insulin secretion [111].

\section{Relation of UCP2 to other pathological conditions}

A deficiency of UCP2 was associated with protection from a parasitic infection [48] but what is not yet known is if the UCP2-deficient mice are more susceptible to age-related diseases, which could result from cumulative oxidative damage to tissues [147]. Future studies to examine a role for $\mathrm{UCP} 2$ as a protective factor against glucose-induced or lipid-induced ROS damage in diabetes and other chronic illnesses associated with ageing will clarify this potential role.

\section{Conclusions}

Since its discovery in 1997, at least 200 research papers have showed that despite the fairly ubiquitous distribution of UCP2 in tissues, its regulation and function could be tissue-specific. Evidence to support a role for UCP2 in adaptive thermogenesis is weak but there are substantive data suggesting that UCP2 could regulate energy homeostasis, particularly under conditions where NEFA are increased like in diabetes mellitus and fasting. The expression of UCP2 in pancreatic beta cells suggests both direct and indirect modulation of NEFA metabolism in skeletal muscle and WAT. In contrast, UCP2 could also limit ROS production, which can protect cells under some circumstances but could also leave animals susceptible to certain infectious processes. Of interest, NEFA exposure has also been associated with an increase in apoptosis in beta cells [148]; therefore a link between the two postulated functions of UCP2 could be tissue lipid exposure. A recent paper assumes that UCP3 could function as an exporter of NEFA from the mitochondrial matrix when their supply is in excess [149]. Such export of anionic NEFA would have the same effect on mitochondrial membrane potential as the import of a proton. Thus, it will be of interest to discover whether UCP2 also acts as a NEFA transporter.

Sources. This review is based on the literature published in the English language since the discovery of UCP2 in 1997 and the earlier publications regarding UCP1 that are key to a background understanding. Sources for the period 1997 to 2001 are searched by PubMed for "uncoupling protein", "reactive oxygen species", and "insulin secretion and lipotoxicity and glucotoxicity".

Acknowledgements. Work done in the authors' laboratories has been supported by grants from the Canadian Diabetes Association and the Canadian Institutes of Health Research. The authors are particularly grateful to J. W. Joseph for his help in producing the figures.

\section{References}

1. Boss O, Hagen T, Lowell BB (2000) Uncoupling proteins 2 and 3: potential regulators of mitochondrial energy metabolism. Diabetes 49: 143-156

2. Dalgaard LT, Pedersen O (2001) Uncoupling proteins: functional characteristics and role in the pathogenesis of obesity and Type II diabetes. Diabetologia 44: 946-965 
3. Ricquier D, Bouillaud F (2000) The uncoupling protein homologues: UCP1, UCP2, UCP3, StUCP and AtUCP. Biochem J 345: 161-179

4. Nicholls DG, Locke RM (1984) Thermogenic mechanisms in brown fat. Physiol Rev 64: 1-64

5. Nagase I, Yoshida T, Kumamoto K et al. (1996) Expression of uncoupling protein in skeletal muscle and white fat of obese mice treated with thermogenic $\beta 3$-adrenergic agonist. J Clin Invest 97: 2898-2904

6. Walker JE, Runswick MJ (1993) The mitochondrial transport protein superfamily. J Bioenerg Biomembr 25: 435-446

7. Runswick MJ, Philippides A, Lauria G, Walker JE (1994) Extension of the mitochondrial super-family: sequences of five members from the nematode worm, Caenorhabditis elegans. DNA Seq 4: 281-291

8. Fleury C, Neverova M, Collins S et al. (1997) Uncoupling protein-2: a novel gene linked to obesity and hyperinsulinemia. Nat Genet 15: 269-272

9. Gimeno RE, Dembski M, Weng X et al. (1997) Cloning and characterization of an uncoupling protein homolog. A potential molecular mediator of human thermogenesis. Diabetes 46: 900-906

10. Enerback S, Jacobsson A, Simpson EM et al. (1997) Mice lacking mitochondrial uncoupling protein are cold-sensitive but not obese. Nature 387: 90-94

11. Boss O, Samec S, Paoloni-Giacobino A et al. (1997) Uncoupling protein-3: a new member of the mitochondrial carrier family with tissue-specific expression. FEBS Lett 408: $39-42$

12. Vidal-Puig A, Solanes G, Grujic D, Flier JS, Lowell BB (1997) UCP3: an uncoupling protein homologue expressed preferentially and abundantly in skeletal muscle and brown adipose tissue. Biochem Biophys Res Commun 235: 79-82

13. Mao W, Yu XX, Zhong A et al. (1999) UCP4, a novel brain-specific mitochondrial protein that reduces membrane potential in mammalian cells. FEBS Lett 443: 326-330

14. Sanchis D, Fleury C, Chomiki N et al. (1998) BMCP1, a novel mitochondrial carrier with high expression in the central nervous system of humans and rodents, and respiration uncoupling activity in recombinant yeast. J Biol Chem 273: 34611-34615

15. Chan CB, MacDonald PE, Saleh MC, Johns DC, Marban E, Wheeler MB (1999) Overexpression of uncoupling protein 2 inhibits glucose-stimulated insulin secretion from rat islets. Diabetes 48: 1482-1486

16. Zhou Y-T, Shimabukura M, Koyama K et al. (1997) Induction by leptin of uncoupling protein-2 and enzymes of fatty acid oxidation. Proc Natl Acad Sci USA 94: 6386-6389

17. Millet L, Vidal H, Andreelli F et al. (1997) Increased uncoupling protein-2 and -3 mRNA expression during fasting in obese and lean humans. J Clin Invest 100: 2665-2670

18. Richard D, Rivest R, Huang Q et al. (1998) Distribution of the uncoupling protein 2 mRNA in the mouse brain. $\mathrm{J}$ Comp Neurol 397: 549-560

19. Diano S, Urbanski HF, Horvath B et al. (2000). Mitochondrial uncoupling protein 2 (UCP2) in the nonhuman primate brain and pituitary. Endocrinology 141: 4226-4238

20. Fleury C, Sanchis D (1999) The mitochondrial uncoupling protein-2: current status. Int $\mathrm{J}$ Biochem Cell Biol 31: 1261-1278

21. Pecqueur C, Alves-Guerra M-C, Gelly C et al. (2001) Uncoupling protein 2: in vivo distribution, induction upon oxidative stress and evidence for translational regulation. J Biol Chem 276: 8705-8712

22. Stuart JA, Harper JA, Brindle KM, Brand MD (1999) Uncoupling protein 2 from carp and zebrafish, ectothermic vertebrates. Biochim Biophys Acta 1413: 50-54

23. Lentes KU, Tu N, Chen H et al. (1999) Genomic organization and mutational analysis of the human UCP2 gene, a prime candidate gene for human obesity. J Recept Signal Transduct Res 19: 229-244

24. Pecqueur C, Cassard-Doulcier A-M, Raimbault S, Miroux B, Fleury C, Gelly C, Bouillaud F, Ricquier D (1999) Functional organization of the human uncoupling protein-2 gene, and juxtaposition to the uncoupling protein-3 gene. Biochem Biophys Res Commun 255: 40-46

25. Kozak LP, Britton JH, Kozak UC, Wells JM (1988) The mitochondrial uncoupling protein gene: correlation of exon structure to transmembrane domains. J Biol Chem 263: $12274-12277$

26. Jaburek M, Varecha M, Gimeno RE et al. (1999) Transport function and regulation of mitochondrial uncoupling proteins 2 and 3. J Biol Chem 274: 26003-26007

27. Winkler E, Klingenberg M (1994) Effect of fatty acids on $\mathrm{H}^{+}$transport activity of the reconstituted uncoupling protein. J Biol Chem 269: 2508-2515

28. Skulachev VP (1992) The laws of cell energetics. Eur J Biochem 208: 203-209

29. Huang SG, Klingenberg M (1996) Chloride channel properties of the uncoupling protein from brown adipose tissue mitochondria: a patch-clamp study. Biochemistry 35 : 16806-16814

30. Gonzalez-Barroso MM, Fleury C, Arechaga T et al. (1996) Activation of the uncoupling protein by fatty acids is modulated by mutations in the C-terminal region of the protein. Eur J Biochem 239: 445-450

31. Bouillard F, Arechaga I, Petit PX et al. (1994) A sequence related to a DNA recognition element is essential for the inhibition by nucleotides of proton transport through the mitochondrial uncoupling protein. EMBO J 13: 1990-1997

32. Jezek P, Orosz DE, Modrianksy M, Garlid KD (1994) Transport of anions and protons by the mitochondrial uncoupling protein and its regulation by nucleotides and fatty acids. A new look at old hypotheses. J Biol Chem 42: 26184-26190

33. Rial E, Gonzalez-Barroso M, Fleury C et al. (1999) Retinoids activate proton transport by the uncoupling proteins UCP1 and UCP2. EMBO J 18: 5827-5833

34. Echtay KS, Winkler E, Frischmuth K, Klingenberg M (2001) Uncoupling proteins 2 and 3 are highly active $\mathrm{H}^{+}$ transporters and highly nucleotide sensitive when activated by coenzyme Q (ubiquinone). Proc Natl Acad Sci USA 98: 1416-1421

35. Himms-Hagen J (1990) Brown adipose tissue thermogenesis: interdisciplinary studies. FASEB J 4: 2890-2898

36. Bianco AC, Kieffer JD, Silva JE (1992) Adenosine 3',5'monophosphate and thyroid hormone control of uncoupling protein messenger ribonucleic acid in freshly dispersed brown adipocytes. Endocrinology 130: 2625-2633

37. Guerra C, Roncero C, Porras A, Fernandez M, Benito M (1996) Triiodothyronine induces the transcription of the uncoupling protein gene and stabilizes its mRNA in fetal rat brown adipocyte primary cultures. J Biol Chem 271: 2076-2081

38. Lowell BB, Susulic VS, Hamann A et al. (1993) Development of obesity in transgenic mice after ablation of brown adipose tissue. Nature 366: 740-742 
39. Scarpace PJ, Matheny M (1998) Leptin induction of UCP1 gene expression is dependent on sympathetic innervation. Am J Physiol 275: E259-E264

40. Zhang Y, Proenca R, Maffei M, Barone M, Leopold L, Friedman JM (1994) Positional cloning of the mouse obese gene and its human homologue. Nature 372: 425-431

41. Chua SC, Chung WK, Wu-Peng XS et al. (1996) Phenotypes of mouse diabetes and rat fatty due to mutations in the OB (leptin) receptor. Science 271: 994-996

42. Cusin I, Zakrzewska KE, Boss O et al. (1998) Chronic central leptin infusion enhances insulin-stimulated glucose metabolism and favors the expression of uncoupling proteins. Diabetes 47: 1014-1019

43. Harper M-E (1997) Obesity research continues to spring leaks. Clin Invest Med 20: 239-244

44. Paulik MA, Buckholz RG, Lancaster ME et al. (1998) Development of infrared imaging to measure thermogenesis in cell culture: thermogenic effects of uncoupling protein-2, troglitazone, and $\beta$-adrenoceptor agonists. Pharm Res 15: 944-949

45. Boss O, Samec S, Dulloo A, Seydoux J, Muzzin P, Giacobino J-P (1997) Tissue-dependent upregulation of rat uncoupling protein-2 expression in response to fasting or cold. FEBS Lett 412: 111-114

46. Yamashita H, Sto Y, Mori N (1999) Difference in induction of uncoupling protein genes in adipose tissues between young and old rats during cold exposure. FEBS Lett 458: 157-161

47. Masaki T, Yoshimatsu H, Chiba S, Sakata (2000) Impaired response of UCP family to cold exposure in diabetic (db/ db) mice. Am J Physiol Regul Integr Comp Physiol 279: R1305-R1309

48. Arsenijevic D, Onuma H, Pecqueur C et al. (2000) Disruption of the uncoupling protein- 2 gene in mice reveals a role in immunity and reactive oxygen species production. Nat Genet 26: 435-439

49. Raimbault S, Dridi S, Denjean F et al. (2001) An uncoupling protein homologue putatively involved in facultative muscle thermogenesis in birds. Biochem J 353: 441-444

50. Jekabsons MB, Gregoire FM, Schonfeld-Warden NA, Warden CH, Horwitz BA (1999) T3 stimulates resting metabolism and UCP-2 and UCP-3 mRNA but not nonphosphorylating mitochondrial respiration in mice. Am J Physiol 277: E380-E389

51. Barbe P, Larrouy D, Boulanger C et al. (2001) Triiodothyronine-mediated upregulation of $\mathrm{UCP} 2$ and $\mathrm{UCP} 3 \mathrm{mR}$ NA expression in human skeletal muscle without coordinated induction of mitochondrial respiratory chain genes. FASEB J 15: 13-15

52. Tu N, Chen H, Winnikes U, Reinert I, Marmann G, Pirke KM, Lentes K-U (1999) Molecular cloning and functional characterization of the promoter region of the human uncoupling protein-2 gene. Biochem Biophys Res Commun 265: 326-334

53. Lanni A, De Felice M, Lombardi A et al. (1997) Induction of UCP2 mRNA by thyroid hormones in rat heart. FEBS Lett 418: 171-174

54. Samec S, Seydoux J, Dulloo AG (1998) Role of UCP homologues in skeletal muscles and brown adipose tissue: mediators of thermogenesis or regulators of lipids as fuel substrate? FASEB J 12: 715-724

55. Roca P, Rodriguez AM, Oliver P et al. (1999) Brown adipose tissue response to cafeteria diet-feeding involves induction of the UCP2 gene and is impaired in female rats as compared to males. Pflugers Arch C Eur J Physiol 438: 628-634
56. Rossmeisl M, Syrovy I, Baumruk F, Flachs P, Janovska P, Kopecky J (2000) Decreased fatty acid synthesis due to mitochondrial uncoupling in adipose tissue. FASEB J 14: 1793-1800

57. Matsuda J, Hosoda K, Itoh H et al. (1997) Cloning of rat uncoupling protein-3 and uncoupling protein-2 cDNAs: their gene expression in rats fed high-fat diet. FEBS Lett 418: 200-204

58. Rippe C, Berger K, Boiers C, Ricquier D, Erlanson-Albertsson C (2000) Effect of high-fat diet, surrounding temperature, and enterostatin on uncoupling protein gene expression. Am J Physiol Endocrinol Metab 279: E293-E300

59. Harrold JA, Widdowson PS, Clapham JC, Williams G (2000) Individual severity of dietary obesity in unselected Wistar rats: relationship with hyperphagia. Am J Physiol Endocrinol Metab 279: E340-E347

60. Surwit RS, Wang S, Petro AE et al. (1998) Diet-induced changes in uncoupling proteins in obesity-prone and obesity-resistant strains of mice. Proc Natl Acad Sci USA 95: 4061-4065

61. Watson PM, Commins SP, Beiler RJ, Hatcher HC, Gettys TW (2000) Differential regulation of leptin expression and function in $\mathrm{A} / \mathrm{J}$ vs. C57BL/6 J mice during diet-induced obesity. Am J Physiol Endocrinol Metab 279: E356-E365

62. York B, Truett AA, Monteiro MP et al. (1999) Gene-environment interaction: a significant diet-dependent obesity locus demonstrated in a congenic segment on mouse chromosome 7. Mamm Genome 10: 457-462

63. Oberkofler H, Liu YM, Esterbauer H, Hell E, Krempler F, Patsch W (1998) Uncoupling protein-2 gene: reduced mRNA expression in intraperitoneal adipose tissue of obese humans. Diabetologia 41: 940-946

64. Pedersen SB, Borglum JD, Kristensen K, Norrelund H, Otto J, Jorgensen L, Richelsen B (2000) Regulation of uncoupling protein (UCP) 2 and 3 in adipose and muscle tissue by fasting and growth hormone treatment in obese humans. Int J Obes Relat Metab Disord 24: 968-975

65. Boivin M, Camirand A, Carli F, Hoffer LJ, Silva JE (2000) Uncoupling protein-2 and -3 messenger ribonucleic acids in adipose tissue and skeletal muscle of healthy males: variability, factors affecting expression, and relation to measures of metabolic rate. J Clin Endocrinol Metab 85: 1975-1983

66. Nisoli E, Carruba MO, Tonello O, Macor C, Federspil G, Vettor R (2000) Induction of fatty acid translocase/ CD36, peroxisome proliferator-activated receptor- $\gamma 2$, leptin, uncoupling proteins 2 and 3 , and tumor necrosis factor- $\alpha$ gene expression in human subcutaneous fat by lipid infusion. Diabetes 49: 319-324

67. Khalfallah Y, Fages S, Laville M, Langin D, Vidal H (2000) Regulation of uncoupling protein-2 and uncoupling protein-3 mRNA expression during lipid infusion in human skeletal muscle and subcutaneous adipose tissue. Diabetes 49: 25-31

68. Tsuboyama-Kasaoka N, Takahashi M, Tanemura K et al. (2000) Conjugated linoleic acid supplementation reduces adipose tissue by apoptosis and develops lipodystrophy in mice. Diabetes 49: 1534-1542

69. Hun CS, Hasegawa K, Kawabata T, Kato M, Shimokawa T, Kagawa Y (1999) Increased uncoupling protein 2 mRNA in white adipose tissue, and decrease in leptin, visceral fat, blood glucose, and cholesterol in KK-Ay mice fed with eicosapentaenoic and docosahexaenoic acids in addition to linolenic acid. Biochem Biophys Res Commun 259: 85-90 
70. Burcelin R, Kande J, Ricquier D, Girard J (1993) Changes in uncoupling protein and GLUT4 glucose transporter expressions in interscapular brown adipose tissue of diabetic rats: relative roles of hyperglycaemia and hypoinsulinaemia. Biochem J 291: 109-113

71. Scarpace PJ, Matheny M, Pollock BH, Tumer N (1997) Leptin increases uncoupling protein expression and energy expenditure. Am J Physiol 273: E226-E230

72. Pinkney JH, Boss O, Bray GA, Bulmer K, Coppack SW, Mohamed-Ali V (2000) Physiological relationships of uncoupling protein-2 gene expression in human adipose tissue in vivo. J Clin Endocrinol Metab 85: 2312-2317

73. Savontaus E, Rouru J, Boss O, Huupponen R, Koulu M (1998) Differential regulation of uncoupling proteins by chronic treatments with $\beta 3$-adrenergic agonist BRL 35135 and metformin in obese $\mathrm{fa} / \mathrm{fa}$ Zucker rats. Biochem Biophys Res Commun 246: 899-904

74. Scarpace PJ, Nicolson M, Matheny M (1998) UCP2, UCP3 and leptin gene expression: modulation by food restriction and leptin. J Endocrinol 159: 349-357

75. Viguerie-Bascands N, Saulnier-Blache J-S, Dandine M, Dauzats M, Daviaud D, Langin D (1999) Increase in uncoupling protein-2 mRNA expression by BRL49653 and bromopalmitate in human adipocytes. Biochem Biophys Res Commun 256: 138-141

76. Sivitz WI, Fink BD, Morgan DA, Fox JM, Donohoue PA, Haynes WG (1999) Sympathetic inhibition, leptin, and uncoupling protein subtype expression in normal fasting rats. Am J Physiol 277: E668-E677

77. Memon RA, Hotamisligil GS, Wiesbrock SM et al. (2000) Upregulation of uncoupling protein 2 in genetic obesity: lack of an essential role for leptin, hyperphagia, increased tissue lipid content, and TNF-alpha. Biochim Biophys Acta 1484: 41-50

78. Hidaka S, Yoshimatsu H, Kakuma T et al. (2000) Tissuespecific expression of the uncoupling protein family in streptozotocin-induced diabetic rats. Proc Soc Exp Biol Med 224: 172-177

79. Jezek P, Engstova H, Zackova M et al. (1998) Fatty acid cycling mechanism and mitochondrial uncoupling proteins. Biochem Biophys Acta 1365: 319-327

80. Wahli W, Braissant O, Desvergne B (1995) Peroxisome proliferator-activated receptors: transcriptional regulators of adipogenesis, lipid metabolism and more. .. Chem Biol 2: 261-266

81. Auwerx J (1999) PPAR $\gamma$, the ultimate thrifty gene. Diabetologia 42: 1033-1049

82. Aubert J, Champigny O, Saint-Marc P et al. (1997) Upregulation of UCP-2 gene expression by PPAR agonists in preadipose and adipose cells. Biochem Biophys Res Commun 238: 606-611

83. Camirand A, Marie V, Rabelo R, Silva JE (1998) Thiazolinediones stimulate uncoupling protein-2 expression in cell lines representing white and brown adipose tissues and skeletal muscle. Endocrinology 139: 428-431

84. Kelly LJ, Vicario PP, Thompson GM et al. (1998) Peroxisome proliferator-activated receptors gamma and alpha mediate in vivo regulation of uncoupling protein (UCP-1, UCP-2, UCP-3) gene expression. Endocrinology 139: 4920-4927

85. Rieusset J, Auwerx J, Vidal H (1999) Regulation of gene expression by activation of the peroxisome proliferatoractivated receptor $\gamma$ with rosiglitazone (BRL 49653) in human adipocytes. Biochem Biophys Res Commun 265: 265-271

86. Acin A, Rodriguez M., Rique H, Canet E, Boutin JA, Galizzi JP (1999) Cloning and characterization of the 5' flanking region of the human uncoupling protein 3 (UCP3) gene. Biochem Biophys Res Commun 258: 278-283

87. Medvedev AV, Snedden SK, Raimbault S, Ricquier D, Collins S (2001) Transcriptional regulation of the mouse uncoupling protein-2 gene: double E-box motif is required for PPAR $\gamma$-dependent activation. J Biol Chem 276: 10817-10823

88. Yoshitomi H, Yamazaki K, Tanaka I (1999) Mechanism of ubiquitous expression of mouse uncoupling protein 2 mRNA: control by cis-acting DNA element in 5'-flanking region. Biochem J 340: 397-404

89. Emilsson V, Summers RJ, Hamilton S, Liu Y-L, Cawthorne MA (1998) The effects of the $\beta 3$-adrenoceptor agonist BRL 35135 on UCP isoform mRNA expression. Biochem Biophys Res Commun 252: 450-454

90. Samec S, Seydoux J, Dulloo AG (1998) Interorgan signaling between adipose tissue metabolism and skeletal muscle uncoupling protein homologs: is there a role for circulating free fatty acids? Diabetes 47: 1693-1698

91. Samec S, Seydoux J, Dulloo AG (1999) Skeletal muscle UCP3 and UCP2 gene expression in response to inhibition of free fatty acid flux through mitochondrial $\beta$-oxidation. Pflugers Arch 438: 452-457

92. Samec S, Seydoux J, Dulloo AG (1999) Post-starvation gene expression of skeletal muscle uncoupling protein 2 and uncoupling protein 3 in response to dietary fat levels and fatty acid composition. A link with insulin resistance. Diabetes 48: 436-441

93. Strommer L, El-Ella GA, Kamel A et al. (2001) Upregulation of uncoupling protein homologues in skeletal muscle but not adipose tissue in posttraumatic insulin resistance. Biochem Biophys Res Commun 281, 334-340

94. Hosoda K, Matsuda J, Itoh H et al. (1999) New members of uncoupling protein family implicated in energy metabolism. Clin Exp Pharmacol Physiol 26: 561-562

95. Gong D-W, He Y, Reitman ML (1999) Genomic organization and regulation by dietary fat of the uncoupling protein 3 and 2 genes. Biochem Biophys Res Commun 256: 27-32

96. Vidal-Puig AJ, Rosenbaum M, Considine RC, Leibel RL, Dohm GL, Lowell BB (1999) Effects of obesity and stable weight reduction on UCP2 and UCP3 gene expression in humans. Obes Res 7: 133-140

97. Bao S, Kennedy A, Wojciechowski B, Wallace P, Ganaway E, Garvey WT (1998) Expression of mRNAs encoding uncoupling proteins in human skeletal muscle: effects of obesity and diabetes. Diabetes 47: 1935-1940

98. Simoneau J-A, Kelley DE, Neverova M, Warden $\mathrm{CH}$ (1998) Overexpression of muscle uncoupling protein 2 content in human obesity associates with reduced skeletal muscle lipid utilization. FASEB J 12: 1739-1745

99. Nordfors L, Hoffstedt J, Nyberg B et al. (1998) Reduced gene expression of UCP2 but not UCP3 in skeletal muscle of human obese subjects. Diabetologia 41: 935-939

100. Vidal H, Langin D, Andreelli F, Millet L, Larrouy D, Laville M (1999) Lack of skeletal muscle uncoupling protein 2 and 3 mRNA induction during fasting in type- 2 diabetic subjects. Am J Physiol 277: E830-E837

101. Schrauwen P, Schaart G, Saris WHM et al. (2000) The effect of weight reduction on skeletal muscle UCP2 and $\mathrm{UCP} 3$ mRNA expression and UCP3 protein content in Type II diabetic subjects. Diabetologia 43: 1408-1416

102. Hjeltnes N, Fernstrom M, Zierath JR, Krook A (1999) Regulation of UCP2 and UCP3 by muscle disuse and physical activity in tetraplegic subjects. Diabetologia 42: $826-830$ 
103. Tonkonogi M, Krook A, Walsh B, Sahlin K (2000) Endurance training increases stimulation of uncoupling of skeletal muscle mitochondria in humans by non-esterified fatty acids: an uncoupling-protein-mediated effect? Biochem J 351: 805-8103

104. Chevillotte E, Rieusset J, Roques M, Desage M, Vidal H (2001) The regulation of uncoupling protein-2 gene expression by $\omega-6$ polyunsaturated fatty acids in human skeletal muscle cells involves multiple pathways, including the nuclear receptor peroxisome proliferator-activated receptor $\beta$. J Biol Chem 276: 10853-10860

105. Koyama K, Chen G, Wang MY et al. (1997) $\beta$-cell function in normal rats made chronically hyperleptinemic by adenovirus-leptin gene therapy. Diabetes 46: 1276-1280

106. Lee Y, Hirose H, Zhou YT, Esser V, McGarry JD, Unger RH (1997) Increased lipogenic capacity of the islets of obese rats: a role in the pathogenesis of NIDDM. Diabetes 46: 408-41

107. Unger RH (1995) Lipotoxicity in the pathogenesis of obesity-dependent NIDDM.Genetic and clinical implications. Diabetes 44: 863-870

108. Shimabukuro M, Zhou Y-T, Lee Y, Unger RH (1997) Induction of uncoupling protein-2 mRNA by troglitazone in the pancreatic islets of Zucker diabetic fatty rats. Biochem Biophys Res Commun 237: 359-361

109. Chan CB, De Leo D, Joseph JW, McQuaid TS, Ha XF, Xu F, Tsushima RG, Pennefather PS, Salapatek AMF, Wheeler MB (2001) Increased UCP-2 levels in $\beta$-cells are associated with impaired glucose-stimulated insulin secretion: mechanism of action. Diabetes 50: 1302-1310

110. Hong Y, Fink BD, Dillon JS, Sivitz WI (2001) Effects of adenoviral overexpression of uncoupling protein-2 and -3 on mitochondrial respiration in insulinoma cells. Endocrinology 142: 249-256

111. Zhang C-Y, Baffy G, Perret P et al. (2001) Uncoupling protein 2 negatively regulates insulin secretion and is a major link between obesity, $\beta$ cell dysfunction, and type 2 diabetes. Cell 105: 745-755

112. Wang M-Y, Shimabukuro M, Lee Yet al. (1999) Adenovirus-mediated overexpression of uncoupling protein- 2 in pancreatic islets of Zucker diabetic rats increases oxidative activity and improves $\beta$-cell function. Diabetes 48 : 1020-1025

113. Lameloise N, Muzzin P, Prentki M, Assimacopoulos-Jeannet F (2001) Uncoupling protein 2: A possible link between fatty acid excess and impaired glucose-induced insulin secretion? Diabetes 50: 803-809

114. Yamagata K, Furuta H, Oda N et al. (1996) Mutations in the hepatocyte nuclear factor- $4 \alpha$ gene in maturity-onset diabetes of the young. Nature 384: 458-460

115. Wang H, Maechler P, Antinozzi PA, Hagenfeldt KA, Wollheim CB (2000) HNF4 $\alpha$ regulates the expression of pancreatic $\beta$-cell genes implicated in glucose metabolism and nutrient-induced insulin secretion. J Biol Chem 275: 35953-35959

116. Wang H, Antinozzi PA, Hagenfeldt KA, Maechler P, Wollheim CB (2000) Molecular targets of a human HNF1 $\alpha$ mutation responsible for pancreatic beta-cell dysfunction. EMBO J 19: 4257-4264

117. Roduit R, Morin J, Masse F et al. (2000) Glucose down regulates the expression of the PPAR $\alpha$ gene in the pancreatic $\beta$-cell. J Biol Chem 275: 35799-35806

118. Grodsky GM, Bolaffi JL (1992). Desensitization of the insulin-secreting beta cell. J Cell Biochem 48: 3-11

119. Roche E, Farfari S, Witters LA et al. (1998) Long-term expsoure of $\beta$-INS cells to high glucose concentrations in- creases anaplerosis, lipogenesis, and lipogenic gene expression. Diabetes 47: 1086-1094

120. Horvath TL, Warden CH, Hajos M, Lombardi A, Goglia F, Diano S (1999) Brain uncoupling protein 2: uncoupled neuronal mitochondria predict thermal synapses in homeostatic centers. J Neurosci 19: 10417-10427

121. Mizuno T, Miura-Suzuki T, Yamashita H, Mori N (2000) Distinct regulation of brain mitochondrial carrier protein-1 and uncoupling protein- 2 genes in the rat brain during cold exposure and aging. Biochem Biophys Res Commun 278: 691-697

122. Chance B, Sies H, Boveris A (1979) Hydroperoxide metabolism in mammalian organs. Physiol Rev 59: 527-605

123. Skulachev VP (1998) Uncoupling: new approaches to an old problem of bioenergetics. Biochim Biophys Acta 1363: $100-124$

124. Schreck R, Baeuerle PA (1991) A role for oxygen radicals as second messengers. Trends Cell Biol 1: 39-42

125. Sen CK, Packer L (1996) Antioxidant and redox regulation of gene transcription. FASEB J 10: 709-720

126. Moslen MT (1994) Reactive oxygen species in normal physiology, cell injury and phagocytosis. Adv Exp Med Biol 366: 17-27

127. Baeuerle PA, Henkel T (1994) Function and activation of $\mathrm{NF}-x \mathrm{~B}$ in the immune system. Annu Rev Immunol 12: 141-179

128. Kroemer G, Petit P, Zamzami N, Vayssiere J, Mignotte B (1995) The biochemistry of programmed cell death. FASEB J 9: 1277-1287

129. Li L-X, Skorpen F, Egeberg K, Jorgensen IH, Grill V (2001) Uncoupling protein-2 participates in cellular defense against oxidative stress in clonal $\beta$-cells. Biochem Biophys Res Commun 282: 273-277

130. Nishikawa T, Edelstein D, Du XL et al. (2000) Normalizing mitochondrial superoxide production blocks three pathways of hyperglycemic damage. Nature 404: 787-790

131. Negre-Salvayre A, Hirtz C, Carrera G et al. (1997) A role for uncoupling protein-2 as a regulator of mitochondrial hydrogen peroxide generation. FASEB J 11: 809-815

132. Yang SQ, Zhu H, Li Y et al. (2000) Mitochondrial adaptations to obesity-related oxidant stress. Arch Biochem Biophys 378: 259-268

133. Rashid A, Wu T-C, Huang C-C et al. (1999) Mitochondrial proteins that regulate apoptosis and necrosis are induced in mouse fatty liver. Hepatology 29: 1131-1138

134. Memon RA, Tecott LH, Nonogaki K et al. (2000) Up-regulation of peroxisome-proliferator-activated receptors (PPAR- $\alpha$ and PPAR- $\gamma$ ) messenger ribonucleic acid expression in the liver in murine obesity: troglitazone induces expression of PPAR- $\gamma$-responsive adipose tissue-specific genes in the liver of obese diabetic mice. Endocrinology 141: 4021-4031

135. Lee F-YJ, Li Y, Yang EK et al. (1999) Phenotypic abnormalities in macrophages from leptin-deficient, obese mice. Am J Physiol 276: C386-C394

136. Yu XX, Barger JL, Boyer BB, Brand MD, Pan G, Adams SH (2000) Impact of endotoxin on UCP homolog mRNA abundance, thermoregulation, and mitochondrial proton leak kinetics. Am J Physiol Endocrinol Metab 279: E433-E446

137. Cortez-Pinto H, Yang SQ, Lin HZ et al. (1998) Bacterial lipopolysaccharide induces uncoupling protein-2 expression in hepatocytes by a tumor necrosis factor- $\alpha$-dependent mechanism. Biochem Biophys Res Commun 251: 313-319

138. Faggioni R, Shigenaga J, Moser A, Feingold KR, Grunfeld C (1998) Induction of UCP2 gene expression by 
LPS: a potential mechanism for increased thermogenesis during infection. Biochem Biophys Res Commun 244: $75-78$

139. Kimura K, Jung BD, Kanehira K, Irie Y, Canas X, Saito M (1999) Induction of uncoupling protein (UCP) 2 in primary cultured hepatocytes. FEBS Lett 457: 75-79

140. Vidal-Puig AJ, Grujic D, Zhang C-Y et al. (2000) Energy metabolism in uncoupling protein 3 knockout mice. J Biol Chem 275: 16258-16266

141. Gong D-W, Monemdjou S, Gavrilova O et al. (2000) Lack of obesity and normal response to fasting and thyroid hormone in mice lacking uncoupling protein-3. J Biol Chem 275: 16251-16257

142. Li B, Nolte LA, Ju J-S et al. (2000) Skeletal muscle respiratory uncoupling prevents diet-induced obesity and insulin resistance in mice. Nat Med 6: 115-112

143. Clapham JC, Arch JRS, Chapman H et al. (2000) Mice overexpressing human uncoupling protein-3 in skeletal muscle are hyperphagic and lean. Nature 406: 415-418

144. Hidaka S, Kakuma T, Yoshimatsu H, Yasunaga S, Kurokawa M, Sakata T (1998) Molecular cloning of rat uncoupling protein 2 cDNA and its expression in genetically obese Zucker fatty (fa/fa) rats. Biochim Biophys Acta 1389: $178-186$

145. Bray GA, York DA (1979) Hypothalamic and genetic obesity in experimental animals: an autonomic and endocrine hypothesis. Physiol Rev 59: 719-809

146. Higa M, Zhou Y-T, Ravazzola M, Baetens D, Orci L, Unger RH (1999) Troglitazone prevents mitochondrial alterations, $\beta$ cell destruction, and diabetes in obese prediabetic rats. Proc Natl Acad Sci USA 96: 11513-11518

147. Kagawa Y, Cha SH, Hasegawa K, Hamamoto T, Endo H (1999) Regulation of energy metabolism in human cells in aging and diabetes: $\mathrm{F}_{\mathrm{o}} \mathrm{F}_{1}, \mathrm{mtDNA}, \mathrm{UCP}$, and ROS. Biochem Biophys Res Commun 266: 662-676

148. Shimabukuro M, Zhou Y-T, Levi M, Unger RH (1998) Fatty acid-induced beta cell apoptosis: a link between obesity and diabetes. Proc Natl Acad Sci USA 95: 2498-2502

149. Himms-Hagen J, Harper M-E (2001) Physiological role of UCP3 may be export of fatty acids from mitochondria when fatty acid oxidation predominates: an hypothesis. Proc Soc Exp Biol Med 226: 78-84 